\title{
ENGLISH ARTICLE CHOICES BY VIETNAMESE EFL LEARNERS
}

\author{
Nguyen Thi Quyen* \\ Department of English Education, Korea University, \\ 145 Anam-ro, Seongbuk-gu, Seoul 02841, South Korea \\ Received 15 November 2017 \\ Revised 13 March 2018; Accepted 30 March 2018
}

\begin{abstract}
This paper investigates the choice of articles by L1 (first language) Vietnamese learners of L2 (second language) English under the framework proposed by Ionin, Ko and Wexler (2004). According to their Fluctuation Hypothesis and Article Choice Parameter, L2 learners of English whose L1 does not have articles have direct, universal grammar-mediated access to universal semantic features of the article system, i.e. definiteness and specificity. The dual article system of English encodes definiteness, which leads L2 learners whose L1 lacks a proper article system to fluctuate between the two values of the Article Choice Parameter, that is, definiteness and specificity. Although empirical research has been done to examine the acquisition of article system by both L1 and L2 learners as well as to validate the hypothesis, the results obtained from the research appear to be inconclusive, laying a fruitful area for further investigation. The current research was carried out with the aim to enrich L2 data with respect to the article acquisition domain and, more importantly, to examine Ionin et al.'s (2004) conclusions regarding the effect of specificity on the choice of article. The study was also motivated by the scarcity of research looking at how Vietnamese learners of L2 English acquire the target article system.

Keywords: universal grammar, article system, article choice parameter, second language acquisition
\end{abstract}

\section{Introduction}

It is often acknowledged that the English article system is particularly problematic to its learners at every proficiency level. Challenges associated with this grammar notion are often explained from a cross-linguistic perspective in which obviously not every language has an article system like that of English. On the surface level, the English article system does not seem intricate at all compared to other grammatical aspects such as the various forms of verb tenses and complex structures of relative clauses. Nevertheless, difficulties in acquiring the article system may stem from the lack of direct form-function mapping

\footnotetext{
*Email: quyennguyen20121991@gmail.com
}

in article uses. Moreover, to L2 learners of English, article choices are not only rulebased but also semantic-based and pragmaticbased. In other words, L2 learners need to rely on the semantic complexity of English articles along with the discourse context in order to use articles correctly, which makes it exceptionally difficult for L2 learners to master the seemingly simple use of articles.

When examining the errors of article uses by L1 Korean and L1 Russian learners of L2 English, Ionin, Ko and Wexler (2004) found that L2 learners often substituted the definite article the with the indefinite article $a$ in definite contexts where specificity is not well in place and vice versa. Moreover, L2 
learners also displayed a fluctuation pattern in which they switched between distinguishing the and $a$ on the basis of definiteness and distinguishing them on the basis of specificity. From these evidences, they concluded that L2 learners have direct access to a universal grammar-based semantic parameter and specificity as a universal semantic feature of article system does play a role in L2 interlanguage grammar. To further support for this claim, Kim and Lakshmanan (2009) tested the Fluctuation Hypothesis with L1 Korean L2 English speakers and indicated that Korean learners' choice of articles were affected by specificity as can be seen in their interpretation of the as a specificity marker. Meanwhile, Tryzna (2009) presented some evidence against the Fluctuation Hypothesis. In her study, the fluctuation effect was not present in the Polish data group and was found only within a subset of the Chinese data (indefinite singular contexts). Given the inconclusive evidence for the hypothesis, the study will look for and analyze more article acquisition data drawn from speakers of a new language background - also an article-less one - Vietnamese.

The paper is organized as follows. In Section 2, previous studies on the L2 acquisition of English articles that examine the hypothesis proposed by Ionin et al. (2004) are reviewed. A small portion of the paper is devoted to exploring Vietnamese nominal phrases, which lends more support to the fluctuation phenomenon. In the next section, I present my experimental results on the L2 acquisition of English articles by Vietnamese learners. In Section 5, I will discuss the role that specificity plays in the acquisition and provide some additional accounts for article omission. The final section concludes the paper with some follow up questions.

\section{Literature background}

\subsection{Article semantics}

Cross-linguistically, articles encode semantic distinctions such as definiteness and specificity (Ionin et al., 2004). The former notion refers to the state of knowledge shared between the speaker and hearer (or writer/ reader) while the latter refers to the state of knowledge known to the speaker (writer) only. It is important to note that the detailed definitions of definiteness and specificity are not uniform among researchers. Nevertheless, in this study the author adopted the definitions proposed by Ionin et al. (2004), which is given in (1) below:

(1) Definiteness and Specificity: Informal definitions

If a Determiner Phrase (DP) of the form [D NP] is ...

a. [+definite], then the speaker and hearer presuppose the existence of a unique individual in the set denoted by the NP.

b. [+specific], then the speaker intends to refer to a unique individual in the set denoted by the NP and considers this individual to possess some noteworthy property.

(Ionin et al., 2004: 5) $^{(1)}$

In referring to English article system, the definite article the indicates that the referent is already shared between the speaker and the hearer. It marks old, given, or presupposed information while the indefinite article $a$ marks new or asserted information. It is also suggested that the signals referential coherence while the use of $a$ in discourse informs the listener that a new entity is introduced (Murphy, 1997). It is essential to note that English language distinguishes two types of articles on the basis of definiteness, not specificity.

\footnotetext{
${ }^{1} \mathrm{NP}$ is the conventional abbreviated form for noun phrase.
} 


\subsection{Article choice parameter}

Ionin et al. (2004) speculated that if article acquisition is constrained by universal grammar (henceforth UG), article choices must be derived from parameter settings. Therefore, they proposed that article uses are regulated by the Article Choice Parameter (henceforth ACP) whose two settings, specificity and definiteness, determine the overall makeup of the article system in a given language. The ACP is given in (2) below:

(2) A language that has two articles distinguishes them as follows:

a. The Definiteness Setting: articles are distinguished on the basis of definiteness.

b. The Specificity Setting: articles are distinguished on the basis of specificity.

In a cross-linguistic examination of article system in world languages done by Ionin (2003), they observed that English articles exemplify the definiteness setting of the ACP; hence a NP is always indefinite while the NP is always definite. On the other hand, Samoan article system represents specificity setting of the ACP. Its two article le and se in turn denote specific and non-specific DPs. A DP introduced by le can be either definite or indefinite whose reference may be unfamiliar to the hearer. By contrast, se indicates no specific referent and denotes a particular referent whose identity is not known exactly to the speaker. With that in mind, Ionin et al. (2004) concluded that Samoan articles are marked for specificity.

\subsection{Fluctuation Hypothesis}

In an attempt to account for error patterns in L2 article use, Ionin et al. (2004) proposed the Fluctuation Hypothesis. This hypothesis posits that L2 learners have full access to UG principles and parameter-settings and L2 learners fluctuate between different parameter-settings until the input let them to set the parameter to the appropriate value manifested in the target language. Therefore, L2 learners of English whose L1s lack articles may fluctuate between the two settings of the ACP and opt for definiteness (target pattern) or specificity (non-target but expected pattern). Fluctuation manifests itself in the overuse of the definite article the in indefinite specific contexts (henceforth [-definite, +specific]) and indefinite article $a$ in definite non-specific contexts (henceforth $[+$ definite, - specific $]$ ).

\subsection{Recent studies on the Fluctuation Hypothesis}

The following table provides a brief summary of six seminal studies that attempted to either validate or argue against the Fluctuation Hypothesis (henceforth FH) and extended to examine the effect of L1 transfer on the acquisition of L 2 articles. Acquisitional data were elicited from learners of various language backgrounds and by different task types, most of which were adopted from Ionin (2003) and Ionin et al. (2004), only differed in the method of data collection.

Table 1. A summary of recent studies on the acquisition of articles

\begin{tabular}{|c|c|c|c|}
\hline Studies & Purposes & Methods & Results \\
\hline $\begin{array}{c}\text { Article } \\
\text { semantics in L2 } \\
\text { acquisition: The } \\
\text { role of specificity } \\
\text { by Ionin et al. } \\
\text { (2004) }\end{array}$ & $\begin{array}{c}\text { Ionin et al. (2004) proposed } \\
\text { the FH for L2 acquisition } \\
\text { of articles. L2 learners } \\
\text { from L1 article-less have } \\
\text { full access to UG and } \\
\text { two settings of the ACP, } \\
\text { and thus are expected to } \\
\text { fluctuate between the two } \\
\text { settings. }\end{array}$ & $\begin{array}{c}\text { Two groups of } \\
\text { intermediate to advanced } \\
\text { level: } 30 \text { Russians and } \\
40 \text { Koreans } \\
\text { Tasks: a forced-choice } \\
\text { elicitation task and a } \\
\text { written production task }\end{array}$ & $\begin{array}{l}\text { The data supported their FH: } \\
\text { in the absence of L1 transfer, } \\
\text { Russian and Korean learners } \\
\text { of English have access to } \\
\text { article semantics provided } \\
\text { by UG but they fluctuate } \\
\text { between the two options. }\end{array}$ \\
\hline
\end{tabular}




\begin{tabular}{|c|c|c|c|}
\hline $\begin{array}{l}\text { Article choice } \\
\text { in L2 English by } \\
\text { Spanish speakers } \\
\text { by Mayo (2009) }\end{array}$ & $\begin{array}{l}\text { Test the FH with data } \\
\text { from speakers of an L1 } \\
\text { with articles encoding } \\
\text { definiteness (Spanish) }\end{array}$ & $\begin{array}{l}\text { Sixty participants of two } \\
\text { different proficiency } \\
\text { levels } \\
\text { Tasks: a written forced- } \\
\text { choice elicitation similar } \\
\text { to Ionin et al. (2004) }\end{array}$ & $\begin{array}{l}\text { Spanish speakers } \\
\text { overwhelmingly chose the } \\
\text { to mark definiteness and } \\
a \text { to mark indefiniteness } \\
\text { and fluctuation was } \\
\text { insignificant. This results } \\
\text { provided robust evidence } \\
\text { supporting the idea that } \\
\text { there is semantic transfer } \\
\text { of the properties of Spanish } \\
\text { articles onto English } \\
\text { counterparts. }\end{array}$ \\
\hline $\begin{array}{l}\text { The acquisition } \\
\text { of articles in } \\
\text { child second } \\
\text { language } \\
\text { English: } \\
\text { fluctuation, } \\
\text { transfer, or both? } \\
\text { Zdorenko \& } \\
\text { Paradis (2008) }\end{array}$ & $\begin{array}{l}\text { Examine the acquisition of } \\
\text { articles by children from } \\
\text { both article and article-less } \\
\text { languages to determine the } \\
\text { role of L1 transfer and test } \\
\text { the FH. }\end{array}$ & $\begin{array}{l}\text { Longitudinal corpus } \\
\text { of narratives from } 17 \\
\text { L2 children learners of } \\
\text { English (mean age } 5.4 \\
\text { years). Narratives were } \\
\text { elicited from picture } \\
\text { books. Adopt Ionin et } \\
\text { al. (2004)'s analysis } \\
\text { of definiteness and } \\
\text { specificity. Analysis } \\
\text { included article uses with } \\
\text { singular common nouns. } \\
\text { All NPs were specific. }\end{array}$ & $\begin{array}{l}\text { Directionality effect: } \\
\text { Majority of children were } \\
\text { more accurate with article } \\
\text { choice in definite than in } \\
\text { indefinite contexts. } \\
\text { There is a fluctuation } \\
\text { pattern in their article } \\
\text { choice. } \\
\text { There is little evidence } \\
\text { of L1 transfer as both } \\
\text { L1 groups misused the } \\
\text { in [-definite] contexts, } \\
\text { which is presented as } \\
\text { counterevidence to } \\
\text { Ionin, Zubizarreta, and } \\
\text { Maldonado (2008)'s } \\
\text { claim that transfer } \\
\text { overrides fluctuation in } \\
\text { the acquisition of article } \\
\text { systems by L2 learners } \\
\text { whose L1 lacks articles. }\end{array}$ \\
\hline $\begin{array}{l}\text { Acquisition of } \\
\text { article semantics } \\
\text { by child and } \\
\text { adult L2-English } \\
\text { learners } \\
\text { Ionin et al. } \\
\text { (2009) }\end{array}$ & $\begin{array}{l}\text { Examine English article } \\
\text { use by L1 Russian adults } \\
\text { and children to see whether } \\
\text { the fluctuation pattern } \\
\text { is observed for both age } \\
\text { groups. } \\
\text { Examine whether the } \\
\text { specificity effect is present } \\
\text { in both groups and tease } \\
\text { apart three different } \\
\text { explanations for article } \\
\text { misuse - egocentricity, } \\
\text { specificity and explicit } \\
\text { strategies. }\end{array}$ & $\begin{array}{l}\text { Task: Written elicitation } \\
\text { test modeled after the } \\
\text { tests used by Ionin et al. } \\
(2004) \text { : forced choices } \\
\text { are replaced by blanks. } \\
\text { Fillers targeting items } \\
\text { other than articles are } \\
\text { included and used as a } \\
\text { cut-off. } \\
\text { Twenty-one adults (aged } \\
18-22) \text { and } 18 \text { children } \\
\left(5^{\text {th }}-6^{\text {th }} \text { graders }\right) \text { satisfied } \\
\text { the cut-off condition. }\end{array}$ & $\begin{array}{l}\text { Both age groups display } \\
\text { specificity effect in } \\
\text { their choice of articles; } \\
\text { however, adults } \\
\text { overextended specificity } \\
\text { distinction to definites } \\
\text { as well as indefinites } \\
\text { while children made the } \\
\text { specificity distinction with } \\
\text { indefinites only. } \\
\text { Older learners' choice of } \\
\text { articles is more governed by } \\
\text { explicit strategies than by } \\
\text { domain-specific linguistic } \\
\text { knowledge. } \\
\text { Overuse of the in children's } \\
\text { article choice can be } \\
\text { attributed to egocentricity. }\end{array}$ \\
\hline
\end{tabular}




\begin{tabular}{|c|c|c|c|}
\hline $\begin{array}{l}\text { Questioning the } \\
\text { validity of the } \\
\text { Article Choice } \\
\text { Parameter and } \\
\text { the Fluctuation } \\
\text { Hypothesis } \\
\text { Tryzna (2009) }\end{array}$ & $\begin{array}{l}\text { Argue for the reduced } \\
\text { version of the Article } \\
\text { Choice Parameter } \\
\text { Examine the predictive } \\
\text { power of the Fluctuation } \\
\text { Hypothesis }\end{array}$ & $\begin{array}{c}\text { A field study of Samoan } \\
\text { article } \\
\text { 19 L1 Polish and 17 L1 } \\
\text { Chinese (article-less } \\
\text { languages) } \\
\text { Task: a forced-choice } \\
\text { elicitation task in Ionin } \\
\text { et al. (2004): } 10 \text { context } \\
\text { types, } 4 \text { each covering } \\
\text { four categories with } \\
\text { singular and plural NPs } \\
\text { both included. }\end{array}$ & $\begin{array}{l}\text { All [+specific, } \text {-definite], } \\
\text { [-specific, }+ \text { definite], and } \\
{[+ \text { specific, }+ \text { definite }] \text { NPs }} \\
\text { require the same specific } \\
\text { article } l e \text { (as opposed to the } \\
\text { previous claim made by } \\
\text { Ionin et al. }(2004) \text { that } l e \\
\text { mark [+specific, }+ \text { definite }] \\
\text { and [+specific; }- \text { definite }] \\
\text { NPs). This evidence lent } \\
\text { support for a reduced version } \\
\text { of ACP. } \\
\text { The fluctuation effect was } \\
\text { not present in the Polish } \\
\text { data group and was found } \\
\text { only within a subset of the } \\
\text { Chinese data (indefinite } \\
\text { singular context). }\end{array}$ \\
\hline $\begin{array}{l}\text { Article choice } \\
\text { and article } \\
\text { omission in the } \\
\text { L3 German of } \\
\text { native speakers } \\
\text { of Japanese with } \\
\text { L2 English } \\
\text { Jaensch (2009) }\end{array}$ & $\begin{array}{l}\text { Investigate article choice } \\
\text { in the third language } \\
\text { acquisition of German. } \\
\text { Examine the possible } \\
\text { fluctuation effects in L3 } \\
\text { acquisition of DPs and the } \\
\text { effect of proficiency levels } \\
\text { on the acquisition of DPs }\end{array}$ & $\begin{array}{c}39 \text { native speakers of } \\
\text { Japanese learning L3 } \\
\text { German; categorized in } \\
\text { four proficiency levels } \\
\text { (elementary to advanced) } \\
\text { Tasks: A written gap- } \\
\text { filling task which was } \\
\text { designed using similar } \\
\text { categories to those in } \\
\text { Ionin et al. (2004). } \\
\text { An oral elicitation } \\
\text { task which requires } \\
\text { description of colored } \\
\text { pictures involving noun } \\
\text { phrases. }\end{array}$ & $\begin{array}{c}\text { Little evidence of fluctuation } \\
\text { in participants' article choice } \\
\text { on the basis of definiteness/ } \\
\text { specificity; } \\
\text { Persistent omission of } \\
\text { German articles in speech by } \\
\text { the participants unaffected } \\
\text { by their proficiency level. }\end{array}$ \\
\hline
\end{tabular}

The first four studies mentioned above either provided support for the UG-based explaination for the acquisition of article that is, both L1 and L2 learners have direct access to universal article semantics, or further strengthen the specificity effect on article acquisition. Data from Mayo (2009) reinforced the claim that L2 English learners whose L1 has the similar article semantics transfer the propeties of their L1 to L2 English. Evidences from child language data in Zdorenko and Paradis (2008) supported the fluctuation hypothesis but provide counter evidence to L1 transfer as shown in the children whose
L1 has article still misusing the in [-definite] contexts. In Ionin et. al (2009), this finding was accounted by pragmatic egocentrism in young learners. On the other hand, the next two studies presented some evidence against the Fluctuation Hypothesis and thus concluded that the Article Choice Parameter should be considered as linguistic variability other than a parameter. Notably, Tryzna (2009) has provided convincing data that showed Samoan marks the specificity distinction with indefinites but not with definites, which leads to the revised cross-linguistic article grouping as shown in Table 2 below: 
Table 2. The revised article grouping cross-linguistically: Two-article language

\begin{tabular}{|c|c|c|}
\hline \multicolumn{3}{|c|}{ Article grouping by definiteness } \\
\hline & +definite & -definite \\
\hline +specific & & \\
\cline { 1 - 1 } -specific & the & a \\
\hline
\end{tabular}

Under this new grouping, it is expected that if the Fluctuation Hypothesis is validated, the fluctuation effect will be more powerful in [-definite] contexts where L2 learners overuse the in [-definite; +specific] contexts.

\section{Vietnamese nominal phrases}

There he following table presents crosslinguistic comparisons of English and Vietnamese with respect to the semantic properties of DPs.

Table 3. Cross-linguistic comparisons of English and Vietnamese with respect to DPs

\begin{tabular}{|c|c|c|}
\hline & English & Vietnamese \\
\hline 1. Determiners & Yes & No \\
\hline 2. $[ \pm$ definite $]$ & Yes & No \\
\hline
\end{tabular}

Vietnamese does not have articles but has classifiers according to Thompson (1965) and Nguyen (1997). In addition, classifiers appear to be associated with specificity rather than definiteness. The following are examples illustrating some of the nominal properties of Vietnamese:

(3)

a. cốc

cup

"cup(s)/ the $\operatorname{cup}(\mathrm{s}) "$

b. cái cốc

CL cup

"the cup/ a cup"

c. một cái cốc *một cốc

one CL cup one cup

(A null CL is ungrammatical with quantifier) ${ }^{(2)}$

$$
\text { "a cup" }
$$

${ }^{2} \mathrm{CL}$ is a conventional abbreviated form for classifiers; the asterisk (*) conventionally marks the ungrammaticality of the phrases and sentences.

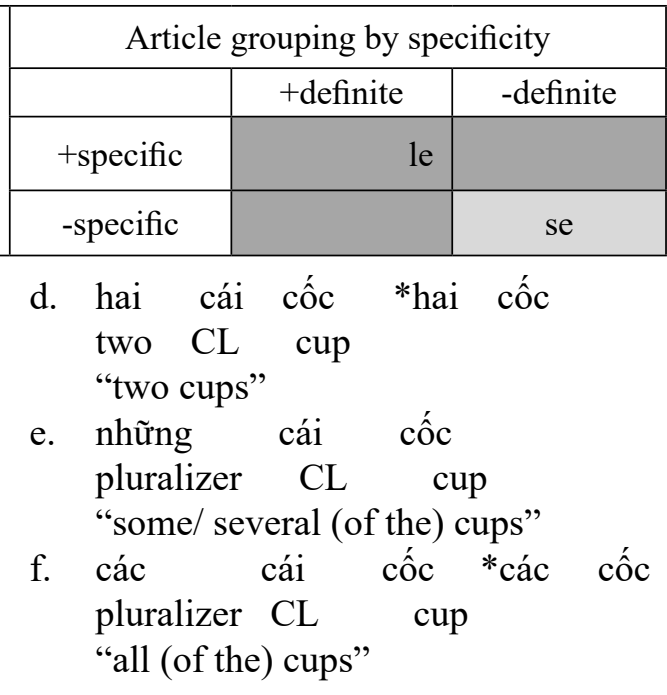

As we can see from (2a), a bare noun in Vietnamese is ambiguous between singularity/ plurality as well as specificity/non-specificity. The use of a classifier in (2b) individualizes the noun and signifies specificity (but ambiguous between definite/ indefinite reading). When the numeral môt (one) is added to CL-N string, the phrase becomes non-specific and indefinite as in (2c). From (2d) to (2f), the noun is pluralized by numerals and quantifiers.

There is no DP in Vietnamese. A bare noun in Vietnamese can be both specific and non-specific while a CL-N string is specific but ambiguous between a definite and an indefinite reading. It is speculated that $[ \pm$ specific] feature is on the Vietnamese CL. A null CL can be either [+specific] or [-specific] while a filled CL bears the value of [+specific].

From what is discussed above, it can be assumed that ifD is absent in their interlanguage grammar, NPs will be mostly treated as bare and interpreted as either [+specific] or [-specific]. Leung (2005) theorized that if D is present in their interlanguage grammar but the feature of [ \pm definite] is not well in place and thus learners may treat D as filled CL, DP may be interpreted as either specific definite or specific indefinite. Subsequently, learners may not be able to distinguish between a definite and an indefinite article: they may treat either the definite or the 
indefinite article as default and over generalize it to both definite and indefinite contexts. This characteristic of Vietnamese CL may lend further support for the claim that specificity may play a role in the acquisition of English article system by Vietnamese learners.

\section{The present study}

\subsection{Research question}

The present study examines the use of L2 English articles by L1 Vietnamese learners. As mentioned earlier, the sole purpose of this paper is to examine the Fluctuation Hypothesis and the effect of specificity (if any) in the acquisition of English article, the research question is formulated as:

Research question: Do Vietnamese

L2 learners of English make the same substitution errors found in Ionin et al. (2004)?

Under the $\mathrm{FH}$, it is predicted that the is overused more in [-definite, +specific] contexts than in the [-definite, -specific] context and $a$ is overused more in [+definite; -specific] contexts than in [+definite; + specific] contexts.

\subsection{Participants}

The participants in this study are first and second year college students at a Vietnamese university located in the Hanoi capital city. All of them are native speakers of Vietnamese and major in TESOL. None of the participants have any experiences living in an English speaking country. The participants were classified into two groups of different proficiency levels as indicated by the class they were placed in. Accordingly, the 56 pre-intermediate learners were first year college students whose levels were between $\mathrm{A} 2$ and $\mathrm{B} 1$ in the Common European Framework of Reference. On the other hand, the 43 intermediate learners were second year college students whose levels were somewhere between B1 and they were working towards B2. In total, there were 99 participants. Their proficiency level was determined by monthly assessment and final exams of four language skills, i.e. listening, speaking, reading, and writing. All the individual tests follow the Cambridge exam format (PET, FCE and CAE). For the current study, no proficiency tests were given to them. The learners were classified according to the given framework by the university together with recommendations from their teachers.

\subsection{The task}

The task was modeled after that used in Ionin et al.'s (2004) study. There were 40 items in total with 32 main test items and 8 additional test items targeting at the equal number of [+definite] contexts and [-definite] contexts. For the main test items, eight categories with four items each were included. Additional test item includes four first-mention indefinites and four previous-mention definites to test if the specificity effects are found in these contexts.

\section{Results}

\subsection{Group results}

In this section, I look at whether L2 learners make the specificity distinction across both definites and indefinites. The predictions examined in this section are described in Table 4 below:

Table 4. Predictions for article choice in L2 English: The specificity distinction with definites and indefinites

\begin{tabular}{|c|c|c|}
\hline & $\begin{array}{c}\text { [+definite] } \\
\text { Target the }\end{array}$ & $\begin{array}{c}\text { [-definite] } \\
\text { Target } \boldsymbol{a}\end{array}$ \\
\hline$[+$ specific] $]$ & correct use of the & overuse of the \\
\hline [-specific] & overuse of $a$ & correct use of $a$ \\
\hline
\end{tabular}

The comparisons between categories were made with paired two-sample $t$ tests for means (two-tailed). In the following tables, only the uses of the and $a$ were reported for ease of presentation. 


\section{Intensional contexts}

First the results for the effects of definiteness and specificity in contexts involving intensional operators are reported in Table 5 and Table 6 below. Table 5 reports data from preintermediate learners while Table 6 reports data from intermediate learners.
As seen from Table 6, there was a significant difference in the use of $a(t=-2.031$, $p=.049)$ and the $(t=2.885, p=.006$ between two categories [ + definite, + specific] and $[+$ definite, - -specific $]$, indicating the significant overuse of $a$ in [ + definite, - -specific] contexts.

Table 5. Definiteness versus specificity: Intensional contexts by pre-intermediate learners

\begin{tabular}{|c|c|c|c|c|}
\hline Contexts & \multicolumn{2}{|c|}{ [+definite] Target: the } & \multicolumn{2}{|c|}{ [-definite] Target: a } \\
\hline [+specific] (wide scope) & $91.1 \%$ the & $7.1 \% a$ & $75 \% a$ & $24.1 \%$ the \\
\hline [-specific] (narrow scope) & $49.1 \%$ the $* 3$ & $23.2 \% a *$ & $83 \% a$ & $15.2 \%$ the \\
\hline
\end{tabular}

$$
\mathrm{N}=56 ;{ }^{*} p<.005
$$

As reported in Table 5, a statistically significant difference was found between two categories [+definite; + specific] and $[+$ definite; -specific] with respect to the use of $a(t=-3.143$, $p=.003)$ and the $(t=7.058, p=.000)$. L2 learners showed a significant overuse of $a$ in [+definite; -specific] context. Between the two categories [-definite; +specific] and [-definite;-specific], there was no significant difference regarding the use of $a(t=-1.540, p=.129)$ and the use of the $(t=1.746, p=.086)$. The overuse of the in [-definite; +specific] context was not statistically significant. However, L2 learners still displayed an overwhelming use of the in [-definite] contexts. However, this result is somewhat contrast with what is expected under the new article grouping as mentioned earlier. L2 learners are expected to display a more significant overuse of the in [-definite] contexts than overuse of $a$ in [ + definite] contexts.
Similarly, the comparisons between two categories [-definite, +specific] and [-definite, -specific] indicated a significant difference in the use of the $(t=-2.988, p=.005)$ and $a(t=$ $3.313, p=.002)$ by L2 intermediate learners.

\section{Extensional contexts}

Next, the results for the effects of definiteness and specificity in extensional contexts in the choice made by two groups, i.e. pre-intermediate learners and intermediate learners, are reported in Table 7 and Table 8 respectively.

Table 6. Definiteness versus specificity: Intensional contexts by intermediate learners

\begin{tabular}{|c|l|c|c|c|}
\hline L1-Vnese & \multicolumn{2}{|c|}{ [+definite] Target: the } & \multicolumn{2}{c|}{ [-definite] Target: a } \\
\hline [+specific] (wide scope) & $90.7 \%$ the & $5.8 \% a$ & $75.6 \% a$ & $22.1 \%$ the \\
\hline [-specific] (narrow scope) & $72.1 \%$ the & $17.4 \% a^{*}$ & $91.9 \% a^{*}$ & $5.8 \%$ the \\
\hline
\end{tabular}

\footnotetext{
${ }^{3}$ In this result section, an asterisk (*) marks a statistically significant probability level.
} 
Table 7. Definiteness versus specificity: Extensional contexts by pre-intermediate learners

\begin{tabular}{|c|c|c|c|c|}
\hline L1-Vnese & \multicolumn{2}{|c|}{ [+definite] Target: the } & \multicolumn{2}{c|}{ [-definite] Target: a } \\
\hline [+specific] (wide scope) & $92.9 \%$ the & $2.7 \% \mathrm{a}$ & $72.3 \% \mathrm{a}$ & $23.2 \%$ the \\
\hline [-specific] (narrow scope) & $59.8 \%$ the* & $13.4 \% \mathrm{a}^{*}$ & $90.2 \% \mathrm{a}^{*}$ & $2.7 \%$ the* \\
\hline
\end{tabular}

As reported in Table 7, a significant difference was found in L2 learners' use of $a(t=-2.698$, $p=.009)$ and the $(t=5.058, p=.000)$ in two contexts $[+$ definite; + specific] and [+definite; -specific], indicating the significant overuse of $a$ in [+definite; -specific] contexts and underuse of target the in [+definite; -specific] contexts. Regarding the [-definite] categories, a significant difference in the use of the was found between [+specific] and [-specific] context $(t=4.509$, $p=.000)$. L2 learners overused the in [-definite; + specific] contexts. statistically significant difference in the use of the in [-definite; +specific] and [-definite; -specific] contexts. Again, this is somewhat contrast to what is expected: L2 learners should have displayed a significant overuse of the in [-definite] contexts.

\section{All contexts combined}

The results on intensional and extensional contexts were combined and reported in graph form in Figure 1 (use of the in four categories) and Figure 2 (use of $a$ in four

Table 8. Definiteness versus specificity: Extensional contexts by intermediate learners

\begin{tabular}{|c|c|c|c|c|}
\hline L1-Vnese & \multicolumn{2}{|c|}{ [+definite] Target: the } & \multicolumn{2}{c|}{ [-definite] Target: a } \\
\hline [+specific] (wide scope) & (11) (31) $93 \%$ the & $3.5 \% \mathrm{a}$ & (15) (35) $83.7 \% \mathrm{a}$ & $4.7 \%$ the \\
\hline [-specific] (narrow scope) & (12) (32) $81.4 \%$ the* & $9.3 \% \mathrm{a}^{*}$ & (16) (36) $93 \% \mathrm{a}^{*}$ & $3.5 \%$ the \\
\hline
\end{tabular}

As reported in Table 8 , a significant overuse of $a$ in [+definite; -specific] context was observed. However, there was not a

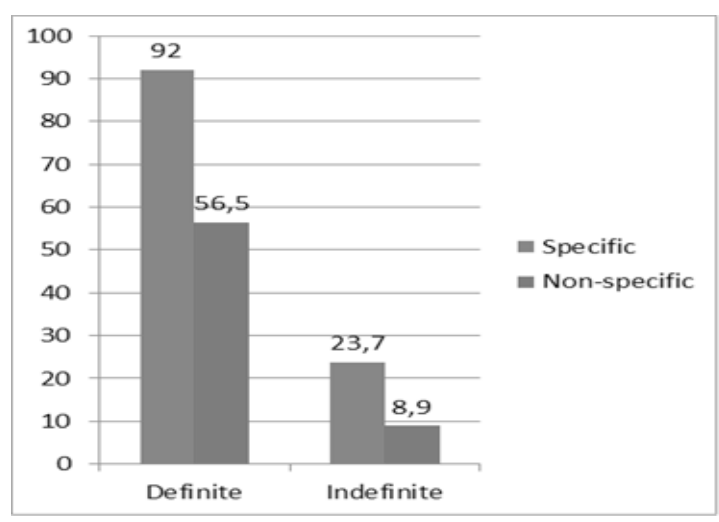

L2 Pre-intermediate categories). The combined results were also presented in Table 9 and 10.

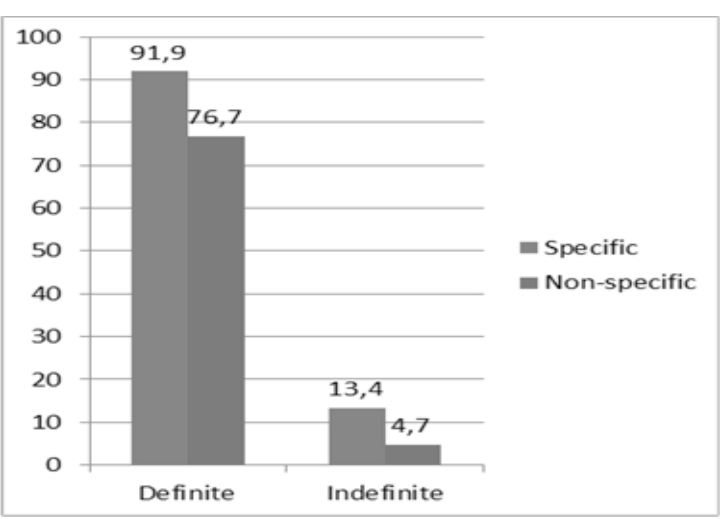

L2 Intermediate

Figure 1: Use of the in 4 categories 


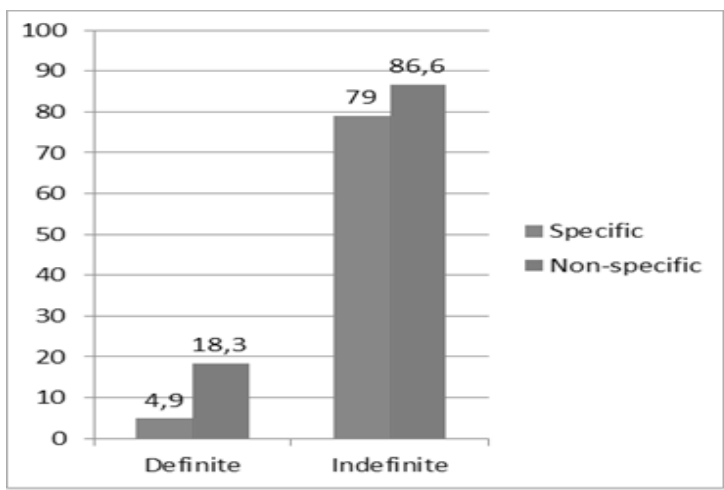

L2 Pre-intermediate

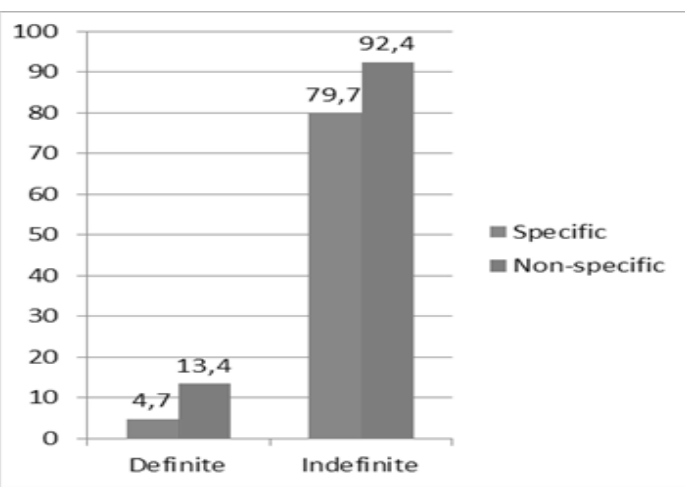

L2 Intermediate

Figure 2: Use of $a$ in 4 categories

Table 9. Definiteness versus specificity: All contexts combined by pre-intermediate learners

\begin{tabular}{|c|c|c|c|c|}
\hline L1-Vnese & \multicolumn{2}{|c|}{ [+definite] Target: the } & \multicolumn{2}{c|}{ [-definite] Target: a } \\
\hline [+specific] (wide scope) & $92 \%$ the & $4.9 \% \mathrm{a}$ & $79 \% \mathrm{a}$ & $23.7 \%$ the \\
\hline [-specific] (narrow scope) & $56.5 \%$ the* & $18.3 \% \mathrm{a}^{*}$ & $86.6 \% \mathrm{a}^{*}$ & $8.9 \%$ the $^{*}$ \\
\hline
\end{tabular}

When all the contexts were combined, L2 pre-intermediate learners showed a significant difference in the use of $a$ between [ + definite; + specific] and [+definite; -specific] contexts $(t=-3.368, p=.001)$ and in the use of the between [-definite; +specific] and [-definite; -specific] contexts $(t=3.886, p=.000)$. learners overused $a$ in [+definite;-specific] contexts where the target article the should be used and overused the in [-definite; +specific] contexts where the target article $a$ should be used. This evidence is in line with the predictions above and thus shows a specificity effect in the choice of articles.

Table 10. Definiteness versus specificity: All contexts combined by intermediate learners

\begin{tabular}{|c|c|c|c|c|}
\hline L1-Vnese & \multicolumn{2}{|c|}{ [+definite] Target: the } & \multicolumn{2}{c|}{ [-definite] Target: a } \\
\hline [+specific] (wide scope) & $91.9 \%$ the & $4.7 \% \mathrm{a}$ & $79.7 \% \mathrm{a}$ & $13.4 \%$ the \\
\hline [-specific] (narrow scope) & $76.7 \%$ the* & $13.4 \% \mathrm{a}^{*}$ & $92.4 \% \mathrm{a}^{*}$ & $4.7 \%$ the $^{*}$ \\
\hline
\end{tabular}

L2 intermediate learners' use of $a$ differed significantly in two contexts [+definite; + specific] and [+definite; -specific] $(t=-$ 2.415, $p=.038)$. There was also a significant difference in the use of the between [-definite; + specific] and [-definite; -specific] contexts $(t=3.458, p=.001)$. The above data suggest that in combining intensional and extensional contexts, both groups of L2 Vietnamese

\section{Effects of definiteness and specificity}

To determine the significance of the contribution of definiteness and specificity to the use of $a$ and the, repeated ANOVAs were performed on the use of the as well as on the use of $a$ by category. To determine the effect of definiteness on the use of the, the number of the that L2 learners used in [+definite, + specific] contexts was measured and then 
compared to the number of the in [-definite, + specific] contexts. The effect on the use of $a$ was determined by a comparison between the uses of $a$ in [ + definite, - -specific] contexts and [-definite, -specific] contexts. To determine the effect of specificity on the use of the, the number of the that $\mathrm{L} 2$ learners used in [+specific, + definite] contexts was measured and then compared to the number of the used in [-specific, + definite] contexts. The effect on the use of $a$ was determined by a comparison between the uses of $a$ in [+specific, -definite] contexts and [-specific, -definite] contexts. The effects of definiteness and specificity are shown in Table 11 below:

Table 11. Effect of definiteness and specificity: Results of repeated measures ANOVA

\begin{tabular}{|c|c|c|}
\hline & Use of the & Use of $a$ \\
\hline L2 Pre-intermediate & & $F(1,55)=232.274^{* *}$ \\
\hline Definiteness & $F(1,55)=210.961^{* *}$ & $F(1,55)=8.98^{*}$ \\
\hline Specificity & $F(1,55)=44.423^{* *}$ & $F(1,42)=274.305^{* *}$ \\
\hline L2 Intermediate & & $\mathrm{F}(1,42)=13.606^{*}$ \\
\hline Definiteness & $F(1,42)=210.61^{* *}$ & $* \mathrm{p}<.005 ; * * \mathrm{p}<.001$ \\
\hline Specificity & $\mathrm{F}(1,42)=1.666$ &
\end{tabular}

Table 11 shows that for both L2 preintermediate and intermediate learners, definiteness and specificity had significant effects on article use, whether the use of the or $a$ were measured. However, in the case of L2 in $[+$ specific, - definite $]$ contexts and the use of $a$ in [-specific; +definite] contexts $(r=.42, p$ $<.005)$. A similar correlation was observed in the case of L2 intermediate learners $(r=.46$, $p<.005)$. This suggests that learners who overused the with [+specific, -definite] were quite likely to overuse $a$ with [-specific, + definite], and vice versa.

\section{First-mention indefinites}

Table 12 shows a comparison of article uses on different types of indefinites. As shown in Table 12, it is predicted that L2 learners should exhibit appropriate use of $a$ on the category of first-mentioned indefinites with no explicit statement of speaker knowledge,

Table 12. Comparison of article uses on different types of indefinites

\begin{tabular}{|c|c|c|c|c|}
\hline Indefinites: Target $\boldsymbol{a}$ & \multicolumn{2}{|c|}{ L2 Pre-intermediate } & \multicolumn{2}{c|}{ L2 Intermediate } \\
\hline [+specific] indefinites & $21.6 \%$ the $*$ & $75.7 \% a$ & $14.8 \%$ the & $81.4 \% a$ \\
\hline [-specific] indefinites & $6.7 \%$ the & $84.8 \% a$ & $5.2 \%$ the $*$ & $88.7 \% a$ \\
\hline $\begin{array}{c}\text { First-mention [-specific] } \\
\text { indefinites }\end{array}$ & $9.4 \%$ the & $71.9 \% a$ & $17.4 \%$ the & $70.3 \% a$ \\
\hline
\end{tabular}

intermediate learners, specificity did not have significant effect on the use of article the. For L2 pre-intermediate learners, there was a significant correlation between the use of the as this category is [-definite, -specific]. L2 learners' performance on this context was expected to resemble to that on [-definite, -specific] in intensional and extensional contexts discussed above.

For L2 pre-intermediate learners, the overuse of the with first-mention indefinites was significantly lower than overuse of the with [+specific, -definite]. This evidence shows that first-mention indefinites patterned 
more with [-specific, - definite] than with [+specific, -definite], as predicted. However, this is not the case with L2 intermediate learners; their overuse of the with firstmention indefinites was significantly higher than that with [-specific, -definite], which is against the prediction.

\section{Previous-mention definites}

Previous-mention definites are obligatorily [+specific] and therefore not expected to trigger a high overuse of $a$ in L2 learners. Their performance with previous-mention definites was predicted to be similar to the performance with [+specific, + definite $]$ contexts. b. The fluctuation pattern: Predicted L2 English learners go back and forth between distinguishing the and $a$ on the basis of definiteness, and distinguishing them on the basis of specificity.

The L2 learners are not expected to display the specificity pattern in which they use the and $a$ to mark [+specific] and [-specific] contexts because the input should lead L2 learners to choose the definiteness rather than the specificity setting. The hypothesis predicts that L2 learners start out fluctuating between the possible parameter-setting provided by UG until the input has informed them that English

Table 13. Comparison of article use on different types of definites

\begin{tabular}{|c|c|c|c|c|}
\hline Definites: Target the & \multicolumn{2}{|c|}{ L2 Pre-intermediate } & \multicolumn{2}{c|}{ L2 Intermediate } \\
\hline [+specific] definites & $82.4 \%$ the & $6.7 \% a$ & $84.6 \%$ the & $6.4 \% a$ \\
\hline [-specific] definites & $49.6 \%$ the & $21.9 \% a^{* *}$ & $68.3 \%$ the & $17.4 \% a^{*}$ \\
\hline $\begin{array}{c}\text { Previous-mention } \\
\text { [+specific] definites }\end{array}$ & $68.8 \%$ the & $19.6 \% a$ & $64.5 \%$ the & $20.9 \% a$ \\
\hline
\end{tabular}

As from Table 13, the results with previous-mention definites are as predicted: they pattern more with $[+$ specific, + definite $]$. For both groups, there was a significant difference between the overuse of $a$ with previous-mention definites and [-specific] definites; however, the difference was not evident between previous-mention definites and $[+$ specific $]$ definites.

\subsection{Individual results}

Possible patterns of individual article choice under the Fluctuation Hypothesis

The Fluctuation Hypothesis predicts that L2 English learners will follow the two following patterns.

a. The definiteness pattern: Predicted L2 English learners correctly use the and $a$ to mark [+definite] and [-definite] contexts, respectively has the definiteness setting of the ACP. It is very unlikely that L2 learners may prefer the specificity setting to the definiteness setting.

\section{Classification procedure}

To test these above predictions, L2 learners' performance on the four main context types was individually measured. Each participant's use of the out of all instances of article use (excluding omission) in the four context types was determined. Afterwards, the learners were classified into four different patterns as summarized in the following procedures as described in Ionin et al. (2004). The partial fluctuation pattern is not described here as none of the participants were classified into this pattern.

Pattern 1: The definiteness pattern: Correct parameter-setting 
At least $75 \%$ the use in $[+$ definite; + specific] contexts

Less than $25 \%$ the overuse in [-definite; -specific] contexts

One of the following:

(i) no specificity distinction with definites or indefinites OR

(ii) a small $(<25 \%)$ specificity distinction with definites only OR

(iii) a small $(<25 \%)$ specificity distinction with indefinites only

Pattern 2: The fluctuation pattern

At least $75 \%$ the use in $[+$ definite; + specific] contexts

Less than $25 \%$ the overuse in [-definite; -specific] contexts

Evidence for a specificity distinction

More overuse of the with [+specific] than with [-specific] indefinites

Less use of the with [-specific] than with [+specific] definites
Pattern 3: The specificity pattern: Parameter mis-setting

At least $75 \%$ of the use in all [+specific] contexts

Less than $25 \%$ of the use in all [-specific] contexts

Equally high use of the with [+specific; + definite] and [+specific; -definite]

Pattern 4: The miscellaneous pattern

Any patterns that do not fit into the above four categories

\section{Individual results}

In the following figures, the numbers of L2 Vietnamese learners in each pattern were reported. As shown in the figure, most L2 learners fell into either the definiteness pattern or the fluctuation pattern as expected. A comparatively small number of learners fell into the miscellaneous pattern and only one learner fell into the specificity pattern.

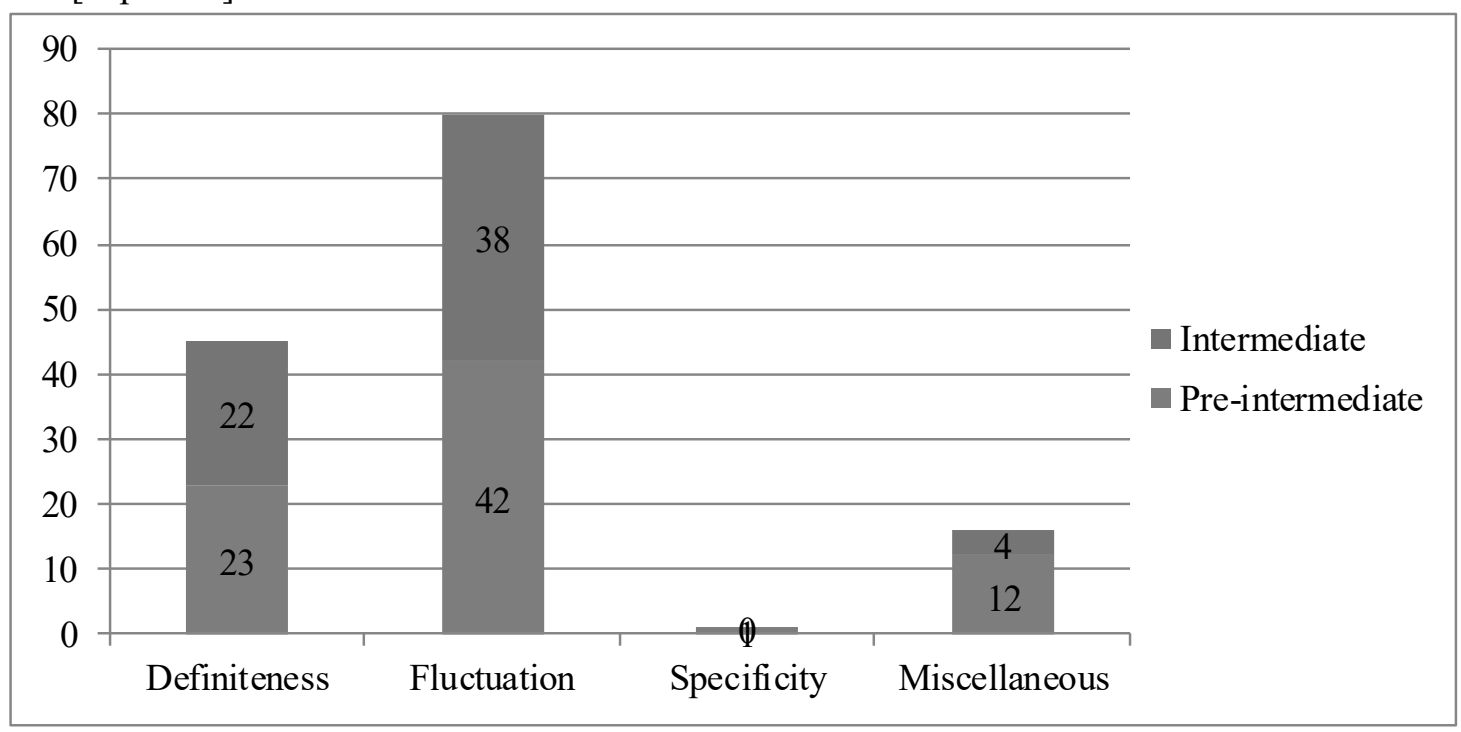

Figure 3. Number of L2 learners showing each pattern

Evidence for a definiteness distinction

More use of the with [+specific] definites and with $[+$ specific $]$ indefinites

The specificity distinction with indefinites does not exceed the specificity distinction with definites by more than $50 \%$ (and vice versa)

\section{Discussion}

\subsection{Group performance}

In what follows I will discuss the predictions regarding the role of specificity with definites and indefinites. The predictions 
and actual results are summarized in Table 14 and Table 15 , respectively. the blank before NPs with a null article. Ionin et al. (2004) data did not show the similar

Table 14. Predictions for L2 English: Definiteness vs. specificity

\begin{tabular}{|c|c|c|}
\hline & [+definite] Target the & [-definite] Target $\boldsymbol{a}$ \\
\hline$[+$ specific] & $\begin{array}{c}\text { correct use of the with items like (1) } \\
\text { and (3) }\end{array}$ & $\begin{array}{c}\text { overuse of the with items like (5) } \\
\text { and (7) }\end{array}$ \\
\hline [-specific] & overuse of $a$ with items like (2) and (4) & $\begin{array}{c}\text { correct use of } a \text { with items like (6) } \\
\text { and (8) }\end{array}$ \\
\hline
\end{tabular}

Table 15. Summary of results in all contexts combined from both groups

\begin{tabular}{|c|c|c|}
\hline & [+definite] Target the & [-definite] Target $\boldsymbol{a}$ \\
\hline [+specific] & correct use of $t h e$ & overuse of $t h e$ \\
\hline [-specific] & overuse of $a$ & correct use of $a$ \\
\hline
\end{tabular}

As can be seen from Table 15, the predictions were supported: L2 learners distinguished between [+specific] and [-specific] DPs with both definites and indefinites. Overall, the pre-intermediate group appears to show a clearer difference from its counterpart as could be explained by their being less proficient than the intermediate group. Nonetheless, qualitatively speaking, both groups used the more in [-definite; +specific] than in [-definite; -specific] contexts and use $a$ more in [+definite; -specific] than in [+definite; + specific] contexts, signaling a specificity intervention in their choice of articles.

These results together with data analysis from individual learners suggest that L2 learners' erroneous substitution of articles are systematic, following an association of the with the feature of [ + specific] rather than [+definite]. The data provide evidence for L2 learners' access to universal semantic distinctions of definiteness and specificity.

\subsection{Accounting for article omission}

The FH cannot account for the high rate of article omission made by L2 Vietnamese learners. The data showed that for item (13) and (14) about half of the L2 learners supplied results. Items (13) and (14) are as follows:

(13) Meeting in a park

Andrew: Hi, Nora. What are you doing here in Chicago? Are you here for work?

Nora: No, for family reasons. I am visiting (a, the, ---) father of my fiancé - he is really nice, and he is paying for our wedding!

(14) Phone conversation

Mathilda: Hi, Sam. Is your roommate Lewis there?

Sam: No, he went to San Francisco for this weekend.

In explaining for this bizarre phenomenon, I come up with two possibilities. The first one can be traced back to Chesterman's (1991) continuum where the zero article is the most indefinite and null article is the most definite one. Perhaps for some reasons L2 Vietnamese learners interpret such NP as mother (of) and father (of) as extremely definite, hence the reason why they marked the NP with the null article. This high rate of article omission can also be traced back to L2 input. Participants reported some follow-up interviews that they found it rather strange to have such NPs denoting family member preceded by a determiner like $a$ and the but favored these NPs to be preceded by possessives. Their exposure with L2 English 
and most likely their production of L2 English with these NPs leads them to believe that the NPs cannot be marked with determiners but possessives instead. More research concerning this issue is definitely desirable.

\section{Conclusion}

In this study, I investigated under the proposal by Ionin et al. (2004) the choice of articles made by Vietnamese speakers whose L1 is article-less. The results are mostly in line with what were reported in their study. I hereby restate their conclusion regarding the proposal. In the absence of L1 transfer, L2 English learners have direct access to universal semantic features of article system. However, as they do not know which settings are applicable for their target language due to limited input and exposure, they end up fluctuating between the two possible settings, i.e. Definiteness and Specificity until the input finally leads them to set the Article Choice Parameter to appropriate value. The conclusion is supported by the data in Ionin et al. (2004), Kim and Lakshamanan (2009) and also this current study. Errors made by L2 learners of English are proved to be systematic and reflective of their access to universal semantics of article system and the fluctuation effects. However, the fluctuation effect is partially held accountable for the errors made by L2 learners; it cannot fully account for all types of errors - omission errors specifically. Therefore, it is necessary to arrive at a framework that can explain for these types of errors.

The present study is not without flaws. It is desirable to have proficiency test to group L2 learners in a more accurate way and include beginner learners so that a developmental path regarding article acquisition can be thoroughly understood. If possible, I will also try to come up with a new task type for eliciting data so that we can have a more comprehensive look at the article choice behavior of Vietnamese learners of English.

\section{References}

Ionin, T. 2003. Article Semantics in Second Language Acquisition, Doctoral dissertation, MIT,
Cambridge, Mass.

Ionin, T., Ko, H., \& Wexler, K. 2004. Article semantics in L2-acquisition: the role of specificity. Language Acquisition, 12, 3-69.

Ionin, T. 2006. This is definitely specific: specificity and definiteness in article systems. Natural Language Semantics, 14, 175-234.

Ionin, T., Zubizarreta, M. L., \& Maldonado, S. B. 2008. Sources of linguistic knowledge in the second language acquisition of English articles. Lingua, 118(4), 554-576.

Ionin, T., Zubizarreta, M. L., \& Philippov, V. 2009. Acquisition of article semantics by child and adult L2 English learners. Bilingualism: Language and Cognition, 12(3), 337-361.

Jaensch, C. 2009. Article choice and article omission in the L3 German of native speakers of Japanese with L2 English In M. P. García-Mayo \& R. Hawkins (Eds.), Second Language Acquisition of Articles: Empirical Findings and Theoretical Implications. Amsterdam: John Benjamins, 233-263.

Kim, L. K. \& Lakshmanan, U. (2009). The processing role of the Article Choice Parameter: Evidence from L2 learners of English. Second language acquisition of articles: Empirical findings and theoretical implications, 13-37.

Leung, Y. K. I. (2005). L2 vs. L3 initial state: A comparative study of the acquisition of French DPs by Vietnamese monolinguals and CantoneseEnglish bilinguals. Bilingualism: Language and Cognition, 8(1), 39-61.

Mayo, M. (2009). Article choice in L2 English by Spanish speakers. Second language acquisition of articles: Empirical findings and theoretical implications, 13-37.

Murphy, S. (1997). Knowledge and Production of English Articles by Advanced Second Language Learners, Doctoral dissertation, University of Texas, Austin.

Nguyen, D.-H. (1997). Vietnamese. Amsterdam: John Benjamins.

Thompson, L. (1965/1987). A Vietnamese reference grammar. Originally published by the University of Washington Press. Reprinted by the University of Hawaii Press.

Trenkic, D. (2008). The representation of English articles in second language grammars: Determiners or adjectives?. Bilingualism Language and Cognition, 11(1), 1.

Tryzna, M. (2009). Questioning the validity of the Article Choice Parameter and the Fluctuation Hypothesis. Second language acquisition of articles: Empirical findings and theoretical implications, 49, 67.

Zdorenko, T., \& Paradis, J. (2008). The acquisition of articles in child second language English: fluctuation, transfer or both?. Second Language Research, 24(2), 227-250. 


\title{
CÁCH SỬ DỤNG MẠO TỬ TIẾNG ANH CỦA NGƯờI VIẸT HỌC TIẾNG ANH NHƯ MỘT NGOẠI NGŨ๋
}

\author{
Nguyễn Thị Quyên \\ Khoa Tiếng Anh, Đại học Hàn Quốc, \\ 145 Anam-ro, Seongbuk-gu, Seoul 02841, Hàn Quốc
}

Tóm tắt: Bài báo này trình bày một nghiên cứu về việc sử dụng mạo từ tiếng Anh của người Việt học tiếng Anh như là một ngoại ngữ được tiến hành trong khuôn khổ nghiên cứu của Ionin, Ko và Wexler (2004). Theo như Lý thuyết Dao động (Fluctuation Hypothesis) và Tham biến Mạo từ (Article Choice Parameter) của ba tác giả trên thì đối với người học tiếng Anh như là một ngoại ngữ - trong khi ngôn ngữ mẹ đẻ của họ không có hệ thống mạo từ, sẽ có thể tiếp cận với hệ thống ngữ pháp phổ quát cũng như những đặc trưng ngữ nghĩa phổ quát của hệ thống mạo từ, đó là tính xác định (definiteness) và tính cụ thể (specificity). Hệ thống nhị phân của mạo từ tiếng Anh được phân chia dựa trên tính xác định của cụm danh từ, chứ không phải tính cụ thể: mạo từ the thể hiện tính xác định và mạo từ $a$ thể hiện tính không xác định. Do đó, theo hai lý thuyết trên, việc sử dụng mạo từ của người học tiếng Anh mà ngôn ngữ mẹ đẻ không có hệ thống mạo từ đầy đủ, được dự đoán là sẽ dao động giữa hai giá trị của Tham biến Mạo từ: lúc này người học sẽ dùng mạo từ dựa trên tính cụ thể của cụm danh từ và lúc khác họ sẽ dùng mạo từ dựa trên tính xác định của cụm danh từ. Trên thực tế, theo như dữ liệu nghiên cứu thu thập được trên nhiều đối tượng học ngoại ngữ thì bằng chứng chứng minh tính khả thi cho Lý thuyết Dao động chưa thực sự được đầy đủ và đa diện. Đây chính là động lực để nghiên cứu này được thực hiện: đó là để kiểm chứng lại Lý thuyết Dao động và Tham biến Mạo từ. Ngoài ra, một động lực khác để thực hiện nghiên cứu này: đó là có rất ít những nghiên cứu về việc sử dụng mạo từ tiếng Anh của người Việt.

Tù khoá: ngữ pháp phổ quát, hệ thống mạo từ, Tham biến Mạo từ, sự thụ đắc ngôn ngữ thứ hai 